\title{
Çocuklarda Topuk Ağrısının En Sık Nedeni: Sever Hastalığı
}

\section{The Most Common Cause of Heel Pain in Children: Sever Disease}

\author{
Mahmut Çivilibal, Ibrahim Sungur* \\ Haseki Eğitim ve Araştırma Hastanesi, Çocuk Sağlığı ve Hastalıkları Kliniği, İstanbul, Türkiye \\ *Haseki Eğitim ve Araştırma Hastanesi, Ortopedi ve Travmatoloji Kliniği, Istanbul, Türkiye
}

\section{Özet}

Non-spesifik topuk ağrısı (kalkaneus apofiziti), özellikle fiziksel olarak aşırı aktif olan çocuklarda yaygın bir hastalıktır. Biz, üç aydan beri sağ topuk ağıısı olan on yaşında bir erkek hasta sunduk. Ağrısı son iki haftada artmıştı ve spor aktivitelerinden sonra yürümesine engel olmakta idi. Muayene ve radyografik bulgularla Sever hastalığı tanısı konuldu. Bu olgu, konservatif olarak tedavi edilebilen ve basit önlemlerle kendi kendini sınırlayan Sever hastalığına dikkat çekmek amacıyla sunuldu. (Haseki Tıp Bülteni 2014; 52: 148-9)

Anahtar Sözcükler: Sever hastalığı, topuk ağrısı, apofizit

\section{Giriş}

Fiziksel olarak aşırı aktif çocuklarda, topuk ağrısı genellikle non-spesifiktir. Ağrı aktivite ile şiddetlendiğinde ve bu ağı başka bir nedenle açıklamadığında, "apofizit" olarak adlandırılır (1). Bu makalede, koşma ve zıplama hareketleri sonrası şiddetlenen sağ topuk ağrısı ile getirilen ve Sever hastalığı (kalkaneus apofiziti) tanısı konulan 10 yaşında bir erkek çocuk sunuldu.

\section{Olgu}

On yaşında erkek hasta, sağ topuk ağrısı yakınması ile getirildi. Ağrııının üç ay önce başladığı, iki haftadan beri kötüleştiği ve özellikle basketbol antrenmanından sonra topallayacak kadar ağırlaştığı öğrenildi. Kilo kaybı, ateş
Non-specific heel pain (calcaneal apophysitis) is a common disorder, particularly in physically active children. Here, we present a 10-yearold boy with a three-month history of right heel pain. It had worsened over a two-week period and aggravated by activity. The diagnosis of Sever's disease was made based on clinical and radiological findings. This case highlights the clinical features of Sever's disease that can be self limiting and treated conservatively. (The Medical Bulletin of Haseki 2014; 52: 148-9)

Key Words: Sever's disease, heel pain, apophysitis

ve iştahsızlığı olmayan hastanın bilinen bir travma öyküsü yoktu. Genel durumu iyi, aktif, boy $145 \mathrm{~cm}$ (90. persentil), tartı $32 \mathrm{~kg}$ (50. persentil) ve kan basıncı 95/60 mmHg idi. Sağ ayak topuğunda kalkaneus kemiğinin arkasında belirgin hassasiyeti dışında tüm sistem muayeneleri doğaldı. Laboratuvar tetkiklerinde; hemoglobin 11,4 gr/dl, beyaz küre sayısı $8400 / \mathrm{mm}^{3}$, trombosit sayısı $356,000 / \mathrm{mm}^{3}$, eritrosit sedimentasyon hızı (ESH) $10 \mathrm{~mm} / \mathrm{saat}$, alkalen fosfataz $110 \mathrm{U} / \mathrm{l}$ (normal <270 U/I) ve serum kalsiyum düzeyi 9,3 mg/dl (normal 8,1-10,4 mg/dl) olarak bulundu. Radyografide kalkaneal apofizde skleroz ve fragmantasyon saptandı (Resim 1). Sever hastalığı tanısı konuldu. Sportif aktivitelere ara vermesi ve gastroknemius kasını germe ve güçlendirme hareketleri yapması önerildi. Gerektiğinde kullanmak üzere ibuprofen şurup ve diklofenak jel verildi. 


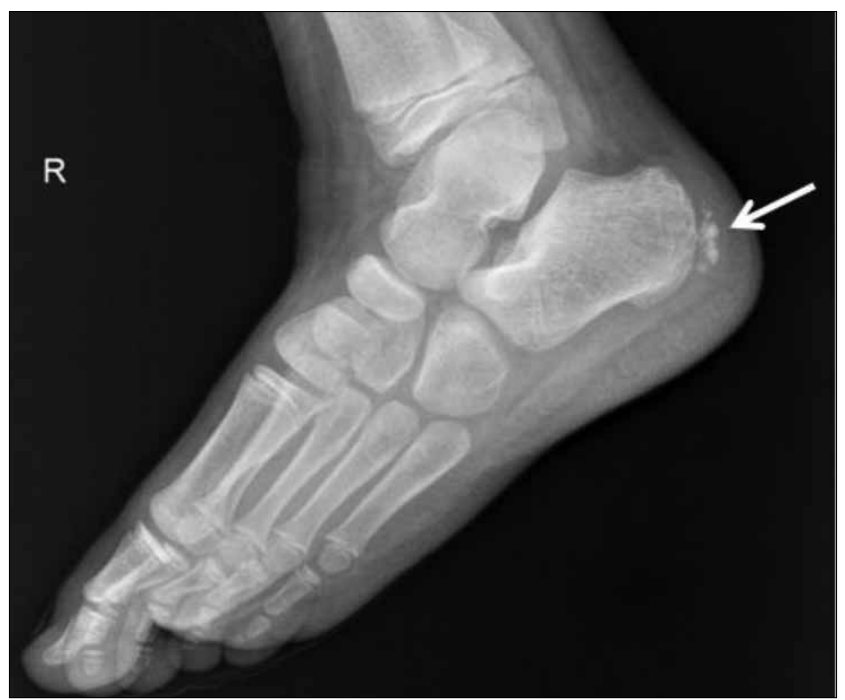

Resim 1. Hastanın lateral ayak grafisinde kalkaneal apofizin dansite artışı ve fragmantasyonu görünümü

\section{Tartışma}

Sever hastalığı, kalkaneus (topuk kemiği) arkasında bulunan büyüme plağının kanlanma bozukluğuna bağlı gelişen aseptik nekrozudur ve çocuklarda topuk ağrısının en sık nedenidir. Özellikle 8-15 yaşlarında, çok aktif, atletik ve kilolu erkek çocuklarında ve gençlerde daha sık görülür. Tekrarlayan koşma ve zıplama hareketleri aşil tendonunun kemiğe yapıştığı yeri çekmeye başlar ve bu bölgede mikrotravmalara neden olur $(1,2)$.

Sever hastalığının en önemli belirtisi genellikle yürüme, koşma veya atlama gibi fiziksel aktivite ile şiddetlenen topuk ağrısıdır. Ağrı kalkaneus apofizinin üzerinde topuğun arka ve plantar tarafına lokalizedir. Bazen, ağrı o kadar şiddetli olabilir ki spor esnasında topallamaya ve fiziksel performansın aksamasına neden olur (3). Hastamız 10 yaşındaydı ve basketbol antrenmanından sonra topallayacak kadar şiddetlenen sağ topuğunda ağrısı vardı.

Topuğun dış görünümü hemen hemen her zaman normaldir, ödem ve eritem gibi yerel hastalık belirtileri yoktur. Bu hastalıkta aşil tendonunun kalkaneusa yapışma yerinin daha altından topuk alt-arka köşesi arasındaki bölgede ortaya çıkan, topuğa basma ve ayak bileğini dorsifleksiyona zorlama ile artan ağrı en sık bulgudur. Ayrıca, hastamızda olduğu gibi topuğun arka bölgesi bastırmakla hassastır ve buna "sıkma testi" denilir. Parmak ucuna basarak yürüme sırasında aşil tendonunun çekmesine bağıı bu bölgede ağıı ortaya çıkabilir $(4,5)$.
Başlangıçta ayak grafileri genellikle normaldir. Bu nedenle Sever hastalığı öncelikle klinik olarak tanınır (1). Radyolojik incelemeler ayırıcı tanıda veya şüpheli durumlarda yardımcıdır. Normalde radyolojik olarak homojen ve düzenli görünümde olması gereken apofiz, homojenitesini kaybeder, düzensizleşir, bazen benekli, bazen de aşııı yoğunlaşma sonucu fildişi görünümü kazanır, bazen de parçalı bir görüntüde olur. Parçalanmış veya sklerotik kalkaneal apofiz, radyolojik tanı için iki önemli ana bulgudur (6-8). Hastamızın sağ ayak lateral grafisinde kalkaneal apofizde dansite artışı ve fragmantasyon olduğu belirlendi (Resim 1). Böylelikle Sever hastalığı tanısı kesinleşti.

Sever hastalığının tedavisi konservatiftir. Tedavi prensipleri; hasta bölgenin yükten ve zorlanmalardan kurtarılması, atlama veya zıplama tarzı sporlardan uzak durulması, topukta yumuşak tabanlıklar kullanılması, gastroknemius-soleus kas kompleksini germe ve güçlendirme hareketleri ve gerekirse anti-enflamatuar ve analjezik ilaç kullanımı ve buz uygulamaları şeklindedir $(5,8)$.

Sonuç olarak, Sever hastalığı hareketli çocuklarda sık görülen, selim ancak yaşam kalitesini bozabilen bir durumdur. Bu olgu sunumunda, hastalığa dikkat çekmek ve ortopedistlerin çok iyi bildiği Sever hastalığı konusunda pediatristlerde de farkındalık yaratmak amaçlandı.

\section{Kaynaklar}

1. Kose O. Do we really need radiographic assessment for the diagnosis of non-specific heel pain (calcaneal apophysitis) in children? Skeletal Radiol 2010;39:359-61.

2. Lau LL, Mahadev A, Hui JH. Common lower limb sport-related overuse injuries in young athletes. Ann Acad Med Singapore 2008;37:315-9.

3. Cassas KJ, Cassettari-Wayhs A. Childhood and adolescent sports-related overuse injuries. Am Fam Physician 2006;73:1014-22.

4. Madden CC, Mellion MB. Sever's disease and other causes of heel pain in adolescents. Am Fam Physician 1996;54:19952000.

5. Micheli LJ, Ireland ML. Prevention and management of calcaneal apophysitis in children: an overuse syndrome. J Pediatr Orthop 1987;7:34-8.

6. Volpon JB, de Carvalho Filho G. Calcaneal apophysitis: a quantitative radiographic evaluation of the secondary ossification center. Arch Orthop Trauma Surg 2002;122:33841.

7. Hogan KA, Gross RH. Overuse injuries in pediatric athletes. Orthop Clin North Am 2003;34:405-15.

8. Peck DM. Apophyseal injuries in the young athlete. Am Fam Physician 1995;51:1891-5, 1897-8. 